\title{
Assessing the viability of Legionella pneumophila in environmental samples: regarding the filter application of Ethidium Monoazide Bromide
}

\author{
Michela Consonni ${ }^{1}$, Anna Grassi ${ }^{1}$, Stefania Scuri ${ }^{2}$, Maria Gori ${ }^{3}$, Elisabetta Tanzi ${ }^{3}$ and Marina Tesauro ${ }^{1 *}$ [D
}

\begin{abstract}
Purpose: Analyses of 34 water samples from 13 healthcare structures revealed how culture method and quantitative PCR (qPCR) often differ in the detection of Legionella pneumophila (Lp). With these considerations in hand, culture method, PCR and Ethidium Monoazide Bromide (EMA) qPCR have all been compared in order to detect $L p$ in water samples, identify a method able to speed up the procedures, detect the "viable but not cultivable" bacteria (VBNC) and exclude non-viable bacteria using a commercial kit for extraction and amplification as well as modification of the protocol.

Methods: Pure water samples artificially spiked with viable, non-viable and VBNC Lp ATCC 33152 were analyzed using a commercial kit for both qPCR and EMA-qPCR, while ISO 11731-2-2004 was used for culture method.

Results: Only 35\% (12/34) of the environmental samples were positive in both culture and GPCR methods. With regard to EMA-qPCR, results showed the absence of dye toxicity on viable and VBNC strains and an incomplete effectiveness on the non-viable ones. In both viable and VBNC strains, a decrease of bacterial DNA amplification was recorded as a function of sample dilution but not of EMA concentration.

Conclusions: Discrepancies between culture method and EMA-qPCR were observed and may be due to different causes such as membrane-dye interactions, presence of interfering compounds and the sensitivity of the kit used.

Study significance and impact: In the presence of one or more suspected cases of nosocomial legionellosis, the application of a rapid molecular method able to identify only the viable and VBNC LP would be useful in order to quickly identify the source of infection and to intervene with sanitation treatments. However, seeing that in our experience EMA pretreatment on the filter membrane did not come up with the expected results, it would be necessary to proceed with other experiments and/or different dyes.
\end{abstract}

Keywords: Legionella, Detection, Rapid methods, Water, Environmental health

\footnotetext{
* Correspondence: marina.tesauro@unimi.it

'Environmental hygiene Lab, Department of Biomedical, Surgical and Dental Sciences, University of Milan and Episomi CRC Lab, via Carlo Pascal 36, 20133 Milan, Italy

Full list of author information is available at the end of the article
}

(c) The Author(s). 2021 Open Access This article is licensed under a Creative Commons Attribution 4.0 International License, which permits use, sharing, adaptation, distribution and reproduction in any medium or format, as long as you give appropriate credit to the original author(s) and the source, provide a link to the Creative Commons licence, and indicate if changes were made. The images or other third party material in this article are included in the article's Creative Commons licence, unless indicated otherwise in a credit line to the material. If material is not included in the article's Creative Commons licence and your intended use is not permitted by statutory regulation or exceeds the permitted use, you will need to obtain permission directly from the copyright holder. To view a copy of this licence, visit http://creativecommons.org/licenses/by/4.0/. 


\section{Key points}

- Need for a rapid method able to identify both viable and VBNC Legionella pneumophila

- Modification of the kit protocol and EMA pretreatment directly on filter

- Results with discrepancies, no toxic effects even with increasing dye concentration

\section{Background}

Legionella is a Gram-negative, aerobic obligate bacterium, whose habitats are represented by both natural and artificial aquatic environments, in a free-living form, as parasites of protozoa and within biofilms (Bianchi et al. 2016). Colonization by Legionella occurs more easily if the artificial water network presents stagnation, biofilm, corrosion, limestone and temperatures between $25{ }^{\circ} \mathrm{C}$ and $42{ }^{\circ} \mathrm{C}$.

Legionella, and particularly the species L. pneumophila $(L p)$, is the causative agent of Legionellosis, a generic term used to describe both pneumonic and nonpneumonic forms. Legionella is commonly transmitted by inhalation of contaminated aerosols, originating from air conditioning, cooling towers, hot and cold-water systems, dental units, humidifiers and whirlpool spas, but also by aspiration of contaminated water (Tesauro et al. 2018).

Legionellosis varies from a mild febrile illness (Pontiac fever) to a serious and sometimes fatal form of pneumonia (Legionnaires' disease) with an approximate mortality rate of $10-30 \%$ (Italian guidelines). Elderly, immunocompromised, transplanted and onco-hematological patients are particularly at risk (Fields et al. 2002).

Some authors (Dusserre et al. 2008, Ducret et al. 2014, Li et al. 2014, Mansi et al. 2014, Casini et al. 2018) report that $L p$, if undergoing prolonged stress such as continuous disinfection treatments, can enter into a state of low metabolic activity that makes it "viable but not cultivable" (VBNC). VBNC bacteria are not able to replicate in culture but regain virulence when environmental conditions return to optimal, representing a risk for human health.

Laboratory methods currently used for both research and quantification of $L p$ in water are culture method and quantitative PCR (qPCR), both with strengths and limitations.

Culture method allows for the detection and isolation of all Legionella species and gives way to correlating clinical strains with environmental ones. Using this method, however, the results, expressed in colony forming units (CFU), can be reported after some time, usually 11 days after the beginning of the analysis. In addition, an underestimation of Legionella species may occur because culture method detects only viable bacteria and can be influenced by the presence of interfering bacterial flora (Leoni and Legnani, 2001, Collins et al. 2015, Kirschner, 2016, Collins et al. 2017, De Giglio et al. 2020). Otherwise, qPCR strengths regard (i) the ability to amplify and simultaneously quantify the DNA of the species of Legionella, expressing the results in Genomic Units (GU), (ii) the rapid response times from the beginning of the analysis (hours instead of days) and (iii) the capacity to also detect VBNC bacteria (Fittipaldi et al. 2011, Whiley and Taylor 2016, Boss et al. 2018). On the other hand, qPCR, as a substantial limit, also detects the DNA of non-viable bacteria. Furthermore, at the moment, it is not possible to univocally convert GU to CFU (Joly et al. 2006, Shih and Lin, 2006, Ditommaso et al. 2014, Collins et al. 2015, Collins et al. 2017, Reyneke et al. 2017, Whiley and Taylor 2016, Boss et al. 2018), as required by national and international guidelines.

To overcome this problem, some authors (Chang et al. 2009, Chang et al. 2010, Chen and Chang 2010, Qin et al. 2012, Mansi et al. 2014, Inoue et al. 2015a and Inoue et al., 2015b, Reyneke et al. 2017) highlighted the possibility of adding to qPCR a pretreatment on the bacterial cells with Ethidium Monoazide Bromide (EMA), a fluorescent dye capable of crossing damaged cell membrane of non-viable bacteria and covalently binding to their DNA. Thereafter, upon exposing the bacterial colonies to a light of $500 \mathrm{~W}$, the dye is activated, with consequent induction of irreversible damage to the nucleic acids which cannot be amplified in a subsequent amplification (Qin et al. 2012, Inoue et al., 2015a, b).

The combination of $\mathrm{qPCR}$ and EMA pretreatment would therefore allow for the amplification of only the DNA of viable and VBNC bacteria, but in this case there are also limits. EMA, being toxic, could penetrate living cells and damage them, causing an underestimation of living bacteria (Reyneke et al. 2017, Boss et al. 2018). Furthermore, in the event of high concentration of non-viable bacteria ( $>10^{5} \mathrm{CFU} / \mathrm{ml}$ ), the amount of EMA may not be enough to inactivate their DNA, with the risk of having false positives (Fittipaldi et al. 2011, Qin et al. 2012). Subsequently, it would be necessary to optimize EMA concentration according to chlorine concentration possibly present in examined water samples. Lastly, it is important to consider the rather significant cost of the method.

The aims of this work were (i) to compare the culture and the qPCR methods on water samples collected from 13 healthcare structures, (ii) to apply and develop the EMA qPCR, using a commercial kit and modifying its protocol, in order to identify a rapid method able to speed up the procedures, detect the viable and "viable but not cultivable" bacteria (VBNC) and exclude nonviable bacteria, especially in situations where discriminating is particularly relevant, as in the presence of clusters or outbreaks of Legionellosis. 


\section{Methods}

\section{Sample collection}

Thirty-four samples of cold and hot water were collected using sterile bottles containing Sodium Thiosulfate (LP italiana SpA, Milan) after flushing water for $5 \mathrm{~min}$; refrigerated samples were transported to the laboratory where they were analyzed both by culture method and qPCR, within $24 \mathrm{~h}$ of the sampling. The samples were collected from Healthcare Facilities distributed in Lombardy, Piedmont and Liguria (north Italy). Some of these water systems were treated continuously with disinfectants such as chlorine dioxide and monochloramine.

Study design included several phases: (1) applying both culture and molecular analysis to the same water sample; (2) applying and developing EMA qPCR method. Pure water samples, which were artificially spiked with viable, non-viable and VBNC Lp ATCC 33152 in serial dilutions, were tested. Initially, 3 different concentrations of the dye (1.25:2.5 and 5 $\mu \mathrm{g} / \mathrm{ml}$ ) were used, and higher concentrations (2.5, 10 and 20 $\mu \mathrm{g} / \mathrm{ml}$ ) were subsequently tested. Non-viable cells were obtained by heat treating, in an incubator, at $95{ }^{\circ} \mathrm{C}$ for 15 min (Qin et al. 2012, Ditommaso et al. 2015, Slimani et al. 2012) while VBNC cells were treated at $59{ }^{\circ} \mathrm{C}$ for $30 \mathrm{~min}$ (Slimani et al. 2012).

\section{Culture method in environmental samples}

ISO 11731-2-2004 "Water quality-detection and enumeration of Legionella" Part 2: "Direct membrane filtration method for waters with low bacterial counts" was followed to test viable cells through culture method (ISO 2014). Briefly, after filtration, the cellulose acetate membrane $(0.22 \mu \mathrm{m})$ was placed directly on GVPN Agar Base medium and Petri dishes were incubated in an incubator with $\mathrm{CO}_{2}$ at $2.5 \%$, at $37{ }^{\circ} \mathrm{C}$ for 10 days. Subsequently, suspicious colonies were tested for genus identification both on BCYE Agar and CYE Agar (ThermoFisher Scientific, Oxoid, Rodano, Italy) and only those which were BYCE positive were verified through latex agglutination tests (Legionella Latex Test, ThermoFisher Scientific, Oxoid, Rodano, Italy) to identify species and serogroups.

\section{DNA extraction}

The AquaScreen ${ }^{\odot}$ FastExtract, validated according to ISO/TS 12869: 2012, was used to extract DNA from water samples, following the instructions provided by the manufacturer (see details in Fig. 1). Water samples were filtered through the polycarbonate membranes (size pores of $0.45 \mu \mathrm{m})$, provided by the kit, and any bacterium present was subjected to lysis directly onto the membrane, as required by the supplier's protocol. Then, binding, removal of contaminants and elution of DNA were all enacted.

\section{Quantitative PCR}

Bacterial DNA was amplified by qPCR using the AquaScreen $^{\odot}$ Legionella pneumophila kit, validated according

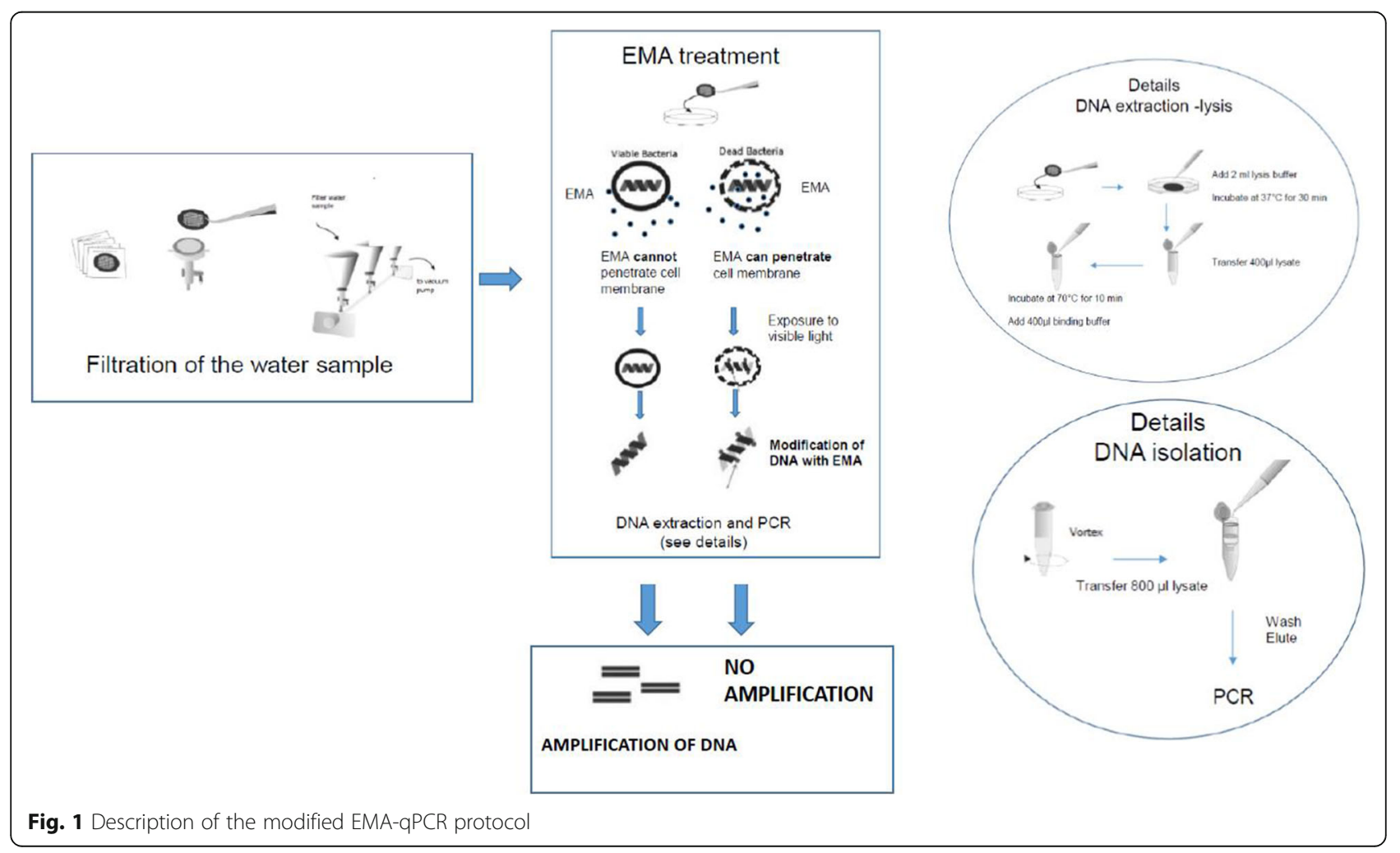


to AFNOR T90-471 and ISO/TS 12869: 2012, following the instructions provided by the manufacturer and using the StepOnePlus Thermocycler (Applied Biosystems, Foster City, CA, USA)

The amplification target is the $L p$ mip gene, which encodes for a protein implicated in the bacterium virulence mechanisms. The related primers are the following: Forward Legmip_f: 5'-GGG (AG)ATT(ACG)T TTATGA AGA TGA (AG)A(CT) TGG; Reverse Legmip_r: 5' TC(AG) TT(ATCG) GG(ATG) CC(ATG) AT(ATCG)GG(ATCG) CC(ATG) CC.

A Reaction Mix, provided by the kit, contained, in addition to an internal control, all required primers, probes, dNTPs and Taq polymerase and was used for the amplification of the extracted DNA.

For each group of samples subjected to amplification, a negative control (PCR grade water), a positive control (provided by the kit) and a series of 6 standard dilutions of $L p$ were also analyzed.

Standard dilutions (PCR Quantification Standard), made from a stock solution of $10^{8} \mathrm{GU}$ provided by the kit, were necessary for the construction of a standard reference curve and the quantification of the amplified DNA (GU).

For the amplification reaction, 1 cycle was performed at $95^{\circ} \mathrm{C}$ for $5 \mathrm{~min}$, followed by 45 cycles composed as so: "denaturation" $\left(95^{\circ} \mathrm{C}\right.$ for $\left.30 \mathrm{~s}\right)$, "annealing" $\left(55^{\circ} \mathrm{C}\right.$ for $\left.30 \mathrm{~s}\right)$ and "elongation and data collection" ( $60^{\circ} \mathrm{C}$ for $\left.45 \mathrm{~s}\right)$.

\section{EMA treatment}

Each pure water sample, artificially spiked for the tests, was filtered using membranes supplied by the AquaScreen FastExtract $(\mathrm{Fx})$ extraction kit and EMA treatment was carried out directly on membranes, to integrate dye treatment to the kit protocol (Fig. 1).

Two different experimental tests were carried out: one with EMA at concentrations of $1.25 ; 2.5$ and $5 \mu \mathrm{g} / \mathrm{ml}$ and a second with EMA at concentrations of 2.5, 10 and $20 \mu \mathrm{g} / \mathrm{ml}$ (Mansi et al. 2014, Qin et al. 2012, Chang et al. 2009, Chen and Chang, 2010, Delgado et al. 2009). Each membrane was placed in a Petri dish and covered with $500 \mu \mathrm{l}$ of EMA at different concentrations. Petri dishes were incubated in an incubator at $21{ }^{\circ} \mathrm{C}$ for $10 \mathrm{~min}$, then placed in a tray with ice and exposed to light for $5 \mathrm{~min}$ $(500 \mathrm{~W})$ at $15 / 20 \mathrm{~cm}$ from the light source (Qin et al. 2012). Lastly, each membrane was taken and placed in a new Petri dish for bacterial DNA extraction and amplification procedures, as provided by kit instructions.

\section{Data interpretation}

Values of threshold cycle $(\mathrm{Ct})$ indicate the presence or absence of $L p$ and the amplification reaction is to be considered positive with $\mathrm{Ct}<40$ and negative with $\mathrm{Ct} \geq$
40 (from AquaScreen Legionella pneumophila Instructions for use).

The detected GUs refer to the total number of bacterial cells, viable and cultivable, viable but not cultivable and non-viable. It should be noted that the AquaScreen ${ }^{\circ}$ Legionella pneumophila kit has a "limit of detection" (LOD) of $20 \mathrm{GU}$ and a "limit of quantification" (LOQ) of $50 \mathrm{GU}$.

The Fisher's exact test, along with sensitivity, specificity and predictive values, was calculated for cultural and GPCR results on water samples from healthcare facilities. The non-parametric linear by linear trend test was applied to the results deriving from $\mathrm{qPCR}$ and EMA-qPCR experiments for viable, VBNC and nonviable strains, using Stata17.0, Stata Corp., College Station, TX, USA 2021.

\section{Results}

Data regarding the comparison between culture method and qPCR, carried out on 34 environmental samples and collected in 13 different Healthcare facilities in north Italy show there is correspondence between positive and negative samples with both methods in 12/34 (35\%) and 9/34 (26\%) cases, respectively. In the other cases, there were discrepancies between the two methods, but no statistically significant difference was detected $(p=$ 0.296 ). Sensitivity and specificity were $70.6 \%$ and $52.9 \%$, while positive and negative predictive values were 60.0 and $64.3 \%$ respectively (Table 1 ). In $9 / 12$ water samples, chlorine dioxide concentration was reported with mean values of $0.32 \mathrm{mg} / \mathrm{L}$ and a range of $0.18-0.58 \mathrm{mg} / \mathrm{L} . L p$ was present in the water network with variable concentrations ranging from "not detected" to $3.3 \mathrm{Log}$ and $50 \%$ of the isolated strains belonged to $L p$ serogroup 1. GUs range from $2.48 \mathrm{Log}$ to $5 \mathrm{Log}$, while only in rare circumstances did high values of CFU/L correspond to high values of GU.

With regards to EMA qPCR, repeated experiments at low dye concentrations (EMA $1.25-2.5-5 \mu \mathrm{g} / \mathrm{ml}$ ) gave differing and controversial results (not reported in this paper) and, in turn, higher concentrations of dye (2.5$10-20 \mu \mathrm{g} / \mathrm{ml}$ ) were verified. For this purpose, diluted samples $\left(1^{\wedge}\right.$ dilution $=10^{5} \mathrm{CFU} / \mathrm{ml} ; 2^{\wedge}$ dilution $=10^{3}$ $\mathrm{CFU} / \mathrm{ml} ; 3^{\wedge}$ dilution $=10^{2} \mathrm{CFU} / \mathrm{ml}$ ) of viable, VBNC and non-viable $L p$ ATCC 33152, prepared from the

Table 1 Comparison between results of cultural and molecular methods on water samples from 13 Healthcare facilities

\begin{tabular}{llll}
\hline & CFUpositive & CFUnegative & \\
\hline qPCR positive & 12 & 8 & 20 \\
qPCR negative & 5 & 9 & 14 \\
& 17 & 17 & 34 \\
& Fisher's exact $p=0.296$ & \\
\hline
\end{tabular}


same stock solution, were analyzed using EMA qPCR and repeated three times over.

As shown in Table 2, we observed a decrease in DNA amplification as a function of sample dilution, both in viable and VBNC strains at all three dye concentrations, almost overlapping. EMA inhibited the DNA amplification of non-viable bacterial cells only at the concentration of $2.5 \mu \mathrm{g} / \mathrm{ml}$ (3rd dilution) and of $10 \mu \mathrm{g} / \mathrm{ml}$ (2nd and 3rd dilution); in the other cases, qPCR detected genetic material. Confirmation that these bacteria died was given by culture method, which always gave results equal to $0 \mathrm{CFU} / \mathrm{L}$.

The test analysis applied to the GUs expressed in logarithmic scale from viable, VBNC and non-viable cells at different EMA concentrations compared to the control qPCR (without treatment) did not reveal statistically significant trends $(p>0.05)$. The same was for each dilution at a defined EMA concentration for the three categories of GUs.

\section{Discussion and conclusion}

Legionnaires' disease represents an emerging problem for public health, especially if it occurs in healthcare facilities, causing not only isolated cases but also clusters or outbreaks. Accordingly, environmental surveillance in health facilities plays an important role in preventing such infections, in order to establish usual or extraordinary treatment interventions to reduce and control the risk of acquiring the infection. Currently, with the aim of detecting and quantifying the rate of contamination in water networks, culture method is considered the gold standard, but qPCR is still possible on water samples, even without international validation.
Many studies confirmed qPCR as a fast and sensitive method to detect and amplify the mip gene of $L p$, while also useful in highlighting VBNC bacteria. Nevertheless, the problem of DNA detection from non-viable bacteria persists, along with other economic and methodological limitations. Other studies highlight the possibility of overcoming the problem of overestimating the presence of non-viable bacterial cells, using Ethidium bromide monoazide (EMA) to bind to the DNA of non-viable cells and prevent its amplification by PCR (EMA-qPCR) (Reyneke et al. 2017).

Culture method, $\mathrm{qPCR}$ and EMA-qPCR, with a variation to the protocol by applying the dye directly to the filter, were compared in the environmental water samples and artificially spiked ones with serial dilutions of alive, non-viable and VBNC Legionella pneumophila ATCC 33152.

The comparison between culture method and qPCR gave overlapping results in most of the cases, showing that the AquaScreen ${ }^{\circ}$ FastExtract kit and AquaScreen ${ }^{\circ}$ Legionella pneumophila kit, respectively for extraction and amplification, have acceptable and satisfactory characteristics. We can hypothesize that discrepancies regarding samples with positive cultures and negative qPCR are due to the presence of ferruginous deposits or other substances, such as residues of disinfection treatments, that may play a role, interfering with DNA extraction and blocking DNA amplification. We cannot exclude that there was also a problem regarding the analytical sensitivity of the q-PRC (20GU/L), being unable to detect very low charges of the microorganism, a condition that often occurs in structures with continuous biocide treatment. In this case, the likelihood of

Table 2 Results of the experiments at the 3 dilutions of viable, VBNC and non-viable cells with EMA at different concentrations ( $\mu \mathrm{g} / \mathrm{ml}$ )

\begin{tabular}{|c|c|c|c|c|}
\hline Dilutions at different EMA concentrations & Viable LogGU/L & VBNC LogGU/L & Non-viableLogGU/L & \\
\hline $1 \wedge \mathrm{qPCR}$ (without EMA) & 10.49 & 10.38 & 9.18 & $p=0.20$ \\
\hline $1 \wedge$ EMA $2.5 \mu \mathrm{g} / \mathrm{ml}$ & 10.15 & 10.31 & 10.38 & $p=0.16$ \\
\hline $1 \wedge \mathrm{EMA} 10 \mu \mathrm{g} / \mathrm{ml}$ & 10.46 & 9.54 & 9.94 & $p=0.43$ \\
\hline \multirow[t]{2}{*}{$1 \wedge \mathrm{EMA} 20 \mu \mathrm{g} / \mathrm{ml}$} & 8.56 & 8.49 & 9.60 & $p=0.84$ \\
\hline & $p=0.22$ & $p=0.10$ & $p=0.72$ & \\
\hline $2^{\wedge} \mathrm{qPCR}$ (without EMA) & 9.11 & 8.72 & 8.97 & $p=0.60$ \\
\hline $2^{\wedge}$ EMA $2.5 \mu \mathrm{g} / \mathrm{ml}$ & 8.78 & 8.55 & 8.85 & $p=0.76$ \\
\hline $2 \wedge \mathrm{EMA} 10 \mu \mathrm{g} / \mathrm{ml}$ & 8.56 & 8.49 & 0.00 & $p=0.22$ \\
\hline \multirow[t]{2}{*}{$2^{\wedge} \mathrm{EMA} 20 \mu \mathrm{g} / \mathrm{ml}$} & 8.84 & 8.53 & 8.15 & $p=0.16$ \\
\hline & $p=0.30$ & $p=0.17$ & $p=0.56$ & \\
\hline $3^{\wedge} \mathrm{qPCR}$ (without EMA) & 8.44 & 8.16 & 7.20 & $p=0.18$ \\
\hline $3 \wedge$ EMA $2.5 \mu \mathrm{g} / \mathrm{ml}$ & 8.24 & 7.85 & 0.00 & $p=0.21$ \\
\hline $3 \wedge$ EMA $10 \mu \mathrm{g} / \mathrm{ml}$ & 8.07 & 7.87 & 0.00 & $p=0.22$ \\
\hline \multirow[t]{2}{*}{$3 \wedge$ EMA $20 \mu \mathrm{g} / \mathrm{ml}$} & 8.21 & 7.79 & 7.76 & $p=0.21$ \\
\hline & $p=0.20$ & $p=0.14$ & $p=0.93$ & \\
\hline
\end{tabular}


acquiring the infection is very small, as demonstrated by the absence of cases of Legionnaire's disease among the patients.

Otherwise, in the case of samples with negative cultures and positive qPCR, we can hypothesize that the presence of non-viable or VBNC bacterial cells has been highlighted, with the amplification of bacterial DNA. Thereby, we consider it essential to try to solve or contain this possibility.

Unfortunately, our experiments with EMA-qPCR were not satisfactory at low concentrations of dye (1.25-2.5-5 $\mu \mathrm{g} / \mathrm{ml}$ ) and even at higher concentrations of $2.5-10-20$ $\mu \mathrm{g} / \mathrm{ml}$. Despite toxicity data to bacteria reported in literature, in our series of tests the dye did not prove to be toxic for live bacteria or even for VBNC ones, observing amplifications at all dilutions. At the same time, it has not been shown to be always effective in inhibiting the amplification of the DNA of non-viable bacterial cells.

Our idea of associating qPCR to the use of dye directly on the filter to evidence VBNC cells and exclude the non-viable ones derived from the necessity to best represent the real contamination from $L p$ in the water network in a short time, which came up in other studies as well. Boss et al. (2018) transferred starved bacteria into a fresh nutritional medium that stimulates them, resulting in a boosted rRNA synthesis, unlike non-viable cells, followed by RT-PCR. Ezenarro et al. (2020) presented a combination of sample concentration, immunoassay detection, and measurement by chronoamperometry. A nitrocellulose microfiltration membrane is used as support for both the water sample concentration and the Legionella immunodetection. Samhan et al. (2017) reported a rapid isothermal amplification method for $L p$ concentration and detection with live/non-viable differentiation under field conditions. Using an on-filter direct amplification (i.e., amplification of cells without DNA extraction and purification) approach with propidium monoazide (PMA), and a real time isothermal amplification platform (Gene-Z), $L p$ could be detected in 1-2 $\mathrm{h}$ at $\sim 1$ CFU $100 \mathrm{ml}$ of tap water. Párraga-Niño et al. (2018) developed a membrane filter method to capture and immunodetect $L p$ in water samples. This membrane filter is used to retain the bacteria using a nitrocellulose disc inside a home-made cartridge. Subsequently the immunodetection of the bacteria retained in the nitrocellulose (blocking, antibody incubation, washings and developing) was performed.

We assumed the same idea to use and optimize the membrane filtration to the following phase of selection of non-viable cells from viable and VBNC ones in our experiments. We chose not to carry out the treatment on pellets but rather directly on membranes in order to use the commercial qPCR kit and to speed up the duration of the analyses. Unfortunately, from our results, we can hypothesize that interactions have occurred between the filter and the dye, making its impact less effective on bacterial cells.

In conclusion, while cultural method remains the gold standard for the research of $L p$ in water, it is necessary to develop alternative methods that allow for the shortening of analytical time and therefore enabling quicker intervention in case of positivity. At the same time, there is still a need to have a laboratory method that can detect VBNC bacteria and exclude non-viable ones. For this purpose, the qPCR could be conducted in parallel with culture method, which proves even better when combined with a pre-treatment that allows for the exclusion of non-viable bacteria. We therefore plan to build upon our experience, modifying conditions of isolation, reagents, or dye.

\section{Acknowledgements}

A special thanks to Dr. Elena Frati, Dr. Vorne Gianelle and Dr. Tommaso Filippini for their help in a part of the analyses.

\section{Authors' contributions}

MT and MC conceived and designed research. MC and AG conducted the experiments. ET contributed with new reagents or analytical tools. AG, SS and MT analyzed the data. MC, AG, MG and MT wrote the manuscript. All authors read and approved the final manuscript.

\section{Funding}

The research was not supported by external funding.

Availability of data and materials

The data analyzed during the current study are available through the corresponding author.

\section{Declarations}

Ethics approval and consent to participate Not applicable.

Consent for publication

Not applicable.

\section{Competing interests}

The authors declare that they have no competing interests.

\section{Author details}

${ }^{1}$ Environmental hygiene Lab, Department of Biomedical, Surgical and Dental Sciences, University of Milan and Episomi CRC Lab, via Carlo Pascal 36, 20133 Milan, Italy. ${ }^{2}$ School of Pharmacy, University of Camerino, Via Madonna delle Carceri, 9 -, 62032 Camerino, MC, Italy. ${ }^{3}$ Department of Health Sciences, University of Milan and Episomi CRC Lab, via Carlo Pascal 36, 20133 Milan, Italy.

Received: 3 June 2021 Accepted: 2 October 2021

Published online: 12 November 2021

\section{References}

Bianchi A, Pregliasco FE, Consonni M, Tesauro M (2016) Genotypic diversity of Legionella pneumophila in environmental and clinical strains assessed by Sequence-Based Typing, in association with retrospective clinical surveillance in Northern Italy. Ann Agric Environ Med 23(2):248-253. https://doi.org/10. 5604/12321966.1203885

Boss R, Baumgartner A, Kroos S, Blattner M, Fretz R, Moor D (2018) Rapid detection of viable Legionella pneumophila in tap water by a qPCR and RTPCR-based method. J Appl Microbiol 125(4):1216-1225. https://doi.org/1 $0.1111 /$ jam. 13932 
Casini B, Baggiani A, Totaro M, Mansi A, Costa AL, Aquino F, Miccoli M, Valentini P, Bruschi F, Lopalco PL, Privitera G (2018) Detection of viable but nonculturable legionella in hospital water network following monochloramine disinfection. J Hosp Infect 98(1):46-52. https://doi.org/10.1016/j.jhin.2017.09. 006

Chang B, Sugiyama K, Taguri T, Amemura-Maekawa J, Kura F, Watanabe H (2009) Specific detection of viable Legionella cells by combined use of photoactivated ethidium monoazide and PCR/real-time PCR. Appl Environ Microbiol 75(1):147-153. https://doi.org/10.1128/AEM.00604-08

Chang B, Taguri T, Sugiyama K, Amemura-Maekawa J, Kura F, Watanabe H (2010) Comparison of ethidium monoazide and propidium monoazide for the selective detection of viable Legionella cells. Jpn J Infect Dis 63(2):119-123

Chen NT, Chang CW (2010) Rapid quantification of viable legionellae in water and biofilm using ethidium monoazide coupled with real-time quantitative PCR. J Appl Microbiol 109(2):623-634. https://doi.org/10.1111/j.1365-2672.201 0.04678

Collins S, Jorgensen F, Willis C, Walker J (2015) Real-time PCR to supplement gold-standard culture-based detection of Legionella in environmental samples. J Appl Microbiol 119(4):1158-1169. https://doi.org/10.1111/jam.12 911

Collins S, Stevenson D, Walker J, Bennett A (2017) Evaluation of Legionella realtime PCR against traditional culture for routine and public health testing of water samples. J Appl Microbiol 122(6):1692-1703. https://doi.org/10.1111/ja m.13461

De Giglio $O$, Diella G, Trerotoli P, Consonni M, Palermo R, Tesauro M, Laganà P, Serio G, Montagna MT (2020) Legionella Detection in Water Networks as per ISO 11731:2017: Can Different Filter Pore Sizes and Direct Placement on Culture Media Influence Laboratory Results? Int J Environ Res Public Health 7(6):2077. https://doi.org/10.3390/ijerph17062077

Ditommaso S, Ricciardi E, Giacomuzzi M, Arauco Rivera SR, Ceccarelli A, Zotti CM (2014) Overestimation of the Legionella spp. load in environmental samples by quantitative real-time PCR: pretreatment with propidium monoazide as a tool for the assessment of an association between Legionella concentration and sanitary risk. Diagn Microbiol Infect Dis 80(4):260-266. https://doi.org/1 0.1016/j.diagmicrobio.2014.09.010

Ditommaso S, Ricciardi E, Giacomuzzi M, Arauco Rivera SR, Zotti CM (2015) Legionella in water samples: how can you interpret the results obtained by quantitative PCR? Mol Cell Probes 29(1):7-12. https://doi.org/10.1016/j.mcp.2 014.09.002

Ducret A, Chabalier M, Dukan S (2014) Characterization and resuscitation of 'nonculturable' cells of Legionella pneumophila. BMC Microbiol 14:3. https://doi. org/10.1186/1471-2180-14-3

Dusserre E, Ginevra C, Hallier-Soulier S, Vandenesch F, Festoc G, Etienne J, Jarraud S, Molmeret M (2008) A PCR-based method for monitoring Legionella pneumophila in water samples detects viable but noncultivable legionellae that can recover their cultivability. Appl Environ Microbiol 74(15):4817-4824 https://doi.org/10.1128/AEM.02899-07

Ezenarro JJ, Párraga-Niño N, Sabrià M, Del Campo FJ, Muñoz-Pascual FX, Mas J, Uria N (2020) Rapid Detection of Legionella pneumophila in Drinking Water, Based on Filter Immunoassay and Chronoamperometric Measurement. Biosensors 10(9):102. https://doi.org/10.3390/bios10090102

Fields BS, Benson RF, Besser RE (2002) Legionella and Legionnaires' disease: 25 years of investigation. Clin Microbiol Rev 15(3):506-526. https://doi.org/10.112 8/cmr.15.3.506-526.2002

Fittipaldi M, Codony F, Adrados B, Camper AK, Morató J (2011) Viable real-time PCR in environmental samples: can all data be interpreted directly? Microb Ecol 61(1):7-12. https://doi.org/10.1007/s00248-010-9719-1

Inoue H, Fujimura R, Agata K, Ohta H (2015a) Molecular characterization of viable Legionella spp. in cooling tower water samples by combined use of ethidium monoazide and PCR. Microbes Environ 30(1):108-112. https://doi.org/10.12 64/jsme2.ME14115

Inoue H, Takama T, Yoshizaki M, Agata K (2015b) Detection of Legionella species in environmental water by the quantitative PCR method in combination with ethidium monoazide treatment. Biocontrol Sci 20(1):71-74. https://doi. org/10.4265/bio.20.71

ISO 11731-2:2004 (2004) Water quality — Detection and enumeration of Legionella - Part 2: Direct membrane filtration method for waters with low bacterial counts. 1st edition, p. 9.

Joly P, Falconnet PA, André J, Weill N, Reyrolle M, Vandenesch F, Maurin M, Etienne J, Jarraud S (2006) Quantitative real-time Legionella PCR for environmental water samples: data interpretation. Appl Environ Microbiol 72(4):2801-2808. https://doi.org/10.1128/AEM.72.4.2801-2808.2006

Kirschner AKT (2016) Determination of viable legionellae in engineered water systems: Do we find what we are looking for? Water Res 93(15):276-288. https://doi.org/10.1016/j.watres.2016.02.016

Leoni E, Legnani PP (2001) Comparison of selective procedures for isolation and enumeration of Legionella species from hot water systems. J Appl Microbiol 90(1):27-33. https://doi.org/10.1046/j.1365-2672.2001.01178

Li L, Mendis N, Trigui H, Oliver JD, Faucher SP (2014) The importance of the viable but non-culturable state in human bacterial pathogens. Front Microbiol 5:258. https://doi.org/10.3389/fmicb.2014.00258

Mansi A, Amori I, Marchesi I, Marcelloni AM, Proietto AR, Ferranti G, Magini V, Valeriani F, Borella P (2014) Legionella spp. survival after different disinfection procedures: Comparison between conventional culture, qPCR and EMAqPCR. Microchemical J 112:65-69. https://doi.org/10.1016/j.microc.2013.09.017

Párraga-Niño N, Quero S, Ventós-Alfonso A, Uria N, Castillo-Fernandez O, Ezenarro JJ, Muñoz FX, Garcia-Nuñez M, Sabrià M (2018) New system for the detection of Legionella pneumophila in water samples. Talanta 189:324-331. https://doi. org/10.1016/j.talanta.2018.07.013

Qin T, Tian Z, Ren H, Hu G, Zhou H, Lu J, Luo C, Liu Z, Shao Z (2012) Application of EMA-qPCR as a complementary tool for the detection and monitoring of Legionella in different water systems. World J Microbiol Biotechnol 28(5): 1881-1890. https://doi.org/10.1007/s11274-011-0986-x

Reyneke B, Ndlovu T, Khan S, Khan W (2017) Comparison of EMA-, PMA- and DNase qPCR for the determination of microbial cell viability. Appl Microbiol Biotechnol 101(19):7371-7383. https://doi.org/10.1007/s00253-017-8471-6

Samhan FA, Stedtfeld TM, Waseem H, Williams MR, Stedtfeld RD, Hashsham SA (2017) On-filter direct amplification of Legionella pneumophila for rapid assessment of its abundance and viability. Water Res 121:162-170. https:// doi.org/10.1016/j.watres.2017.05.028

Shih HY, Lin YE (2006) Caution on interpretation of Legionella results obtained using real-time PCR for environmental water samples. Appl Environ Microbiol 72(10):6859. https://doi.org/10.1128/AEM.00968-06

Slimani S, Robyns A, Jarraud S, Molmeret M, Dusserre E, Mazure C, Facon JP, Lina G, Etienne J, Ginevra C (2012) Evaluation of propidium monoazide (PMA) treatment directly on membrane filter for the enumeration of viable but non cultivable Legionella by qPCR. J Microbiol Methods 88(2):319-321. https://doi. org/10.1016/j.mimet.2011.12.010

\section{Publisher's Note}

Springer Nature remains neutral with regard to jurisdictional claims in published maps and institutional affiliations.
Ready to submit your research? Choose BMC and benefit from:

- fast, convenient online submission

- thorough peer review by experienced researchers in your field

- rapid publication on acceptance

- support for research data, including large and complex data types

- gold Open Access which fosters wider collaboration and increased citations

- maximum visibility for your research: over $100 \mathrm{M}$ website views per year

At BMC, research is always in progress.

Learn more biomedcentral.com/submissions 